\title{
Nový zákon o znalcích v Parlamentu ČR
}

\section{New Act on Experts in the Parliament of the Czech Republic}

Albert Bradáč, emeritní profesor*

\begin{abstract}
Abstrakt
V příspěvku je uveden průběh schvalování vládního návrhu nového zákona o znalcích, znaleckých kancelárích a znaleckých ústavech. Ke dni 29. zárí 2019 je zákon přes zamítnutí Senátem schválen a podepsán panem prezidentem, s účinností za rok a čtvrt, od 1. 1. 2021. Naopak o 60 dní je v Poslanecké sněmovně odloženo projednávání Senátem zamítnutého zákona o soudních tlumočnících a soudních překladatelích, přitom ovšem bylo přehlasováno zamítnutí Senátu u třetího souvisejícího zákona, kterým se mění některé zákony $\mathrm{v}$ souvislosti s přijetím zákona o znalcích, znaleckých kancelárích a znaleckých ústavech a zákona o soudních tlumočnících a soudních překladatelích, takže tento změnový zákon schválen byl.
\end{abstract}

Klíčová slova: znalec, znalecká kancelář, znalecký ústav.

\section{ÚVODEM}

Jak jsme uvedli již v minulém čísle časopisu, Parlament ČR schvaloval nový zákon o znalcích, znaleckých kancelářích a znaleckých ústavech. Závěr projednávání byl až trapný; v následujícím si dovolíme uvést podrobnosti zejména z poslední schůze 10. záŕí 2019 v Poslanecké sněmovně, tak jak je zachycena ve stenografickém protokolu ${ }^{1)}$

Vládní návrh zákona je datován 17. ledna 2018. Po rok a čtvrt trvajícím obšírném a složitém projednávání byl zákon v Poslanecké sněmovně schválen dne 6 . března 2019 na 27 . schůzi.

Následně dne 2. května 2019 zákon projednal Senát, zamítnul jej a vrátil Poslanecké sněmovně. Pro Poslaneckou sněmovnu v př́ípadě zamítnutí platí ustanovení čl. 47 Ústavy ČR ${ }^{2)}$ :

- jestliže Senát návrh zákona zamítne, hlasuje o něm Poslanecká sněmovna znovu. Návrh zákona je prijiat, jestliže je schválen nadpolovični většinou všech poslanců.

\footnotetext{
1) Zdroj: http://www.psp.cz/eknih/2017ps/stenprot/034schuz/s034010.htm\#r2

2) http://www.psp.cz/docs/laws/constitution.html
}

\begin{abstract}
The paper presents the process of approving the government bill for a new law on experts, expert offices and expert institutes. As of 29 September 2019, the bill has been approved and signed by the President with effect from January 1, 2021. On the other hand, the Chamber of Deputies, however, the Senate's rejection of the third related law amending certain laws in connection with the adoption of the Act on Experts, Expert Offices and Expert Institutes and the Act on Certified Translators and Certified Translators was overturned, so this amendment was passed.
\end{abstract}

Key words: expert, expert office, expert institute.

- Pozměnovaci návrhy nejsou při projednáváni zamitnutého nebo vráceného návrhu zákona v Poslanecké sněmovně prípustné.

Poslanecká sněmovna Senátem zamítnutý návrh zákona zařadila na pořad 30. schůze dne 4. 6. 2019 spolu s obdobně Senátem zamítnutými návrhy zákona o soudních tlumočnících a soudních překladatelích a zákona, kterým se mění některé zákony v souvislosti s prrijetím zákona o znalcích, znaleckých kancelárích a znaleckých ústavech a zákona o soudních tlumočnících a soudních překladatelích (změny tr. řádu, zákona o živnostenském podnikání, zákona o soudních poplatcích (zrušení položky č. 36 za jmenování resp. rozšiření oprávnění ...), zákona o pobytu cizinců na území České republiky, zákona o správních poplatcích (nově $500 \mathrm{Kč} \mathrm{za} \mathrm{vydání} \mathrm{průkazu} \mathrm{znalce}$ nebo tlumočníka), o elektronických úkonech a autorizované konverzi dokumentů (MSp bezodkladně informuje MV o zápisu do seznamu znalců, ...). Namísto toho se ovšem na této schůzi Poslanecké sněmovny projednávala předběžná zpráva $\mathrm{z}$ Bruselu o dotacích.

Další projednání zamítnutého zákona bylo stanoveno na 18. června 2019 jako body programu č. 7, 8 a 9; opět neprojednáno, nakonec v pátek dne 21. 6. 2019 vyřazeno z programu 30. schůze. 
Projednávání zákona o znalcích, znaleckých kancelářích a znaleckých ústavech v Poslanecké sněmovně dne 10. 9. 2019

Další schůze byla svolána na úterý 10. 9. 2019 s navrženým programem „zákony zamítnuté a vrácené Senátem“. Znalecký zákon byl projednáván jako první.

Úvodní slovo přednesla ministryně spravedlnosti, paní Mgr. Marie Benešová. Z jejího projevu (ze stenoprotokolu Poslanecké sněmovny) uvádíme:

Dámy a pánové, vážené vedení, pokud jde o zákon o znalcich, znaleckých kancelářich a ústavech, sněmovní tisk čislo 72, nebyl schválen bohužel v Senátu, prestože tento návrh zákona doznal celou r̆adu změn už z Poslanecké sněmovny a ty různé výtky, které byly poměrně četné, byly zapracovány.

Já bych chtěla jenom zdưraznit, že zákon, který je nyni platný, je z roku 1967 a zákon už zcela nevyhovuje. Cílem nového zákona je stabilizovat a zkvalitnit výkon znalecké činnosti a dostat trošku také znalce, kteři, jak vidite, dneska žongluji se znaleckými posudky ve velkém, pod kontrolu. Rozdilných zájmů a názori̊ na znaleckou činnost bylo nespočetně ... a príprava nového zákona byla poměrně náročná, trvala léta, začali ji moji predchůdci a já v podstatě šla obhajovat až do Senátu ten návrh, který prošel Sněmovnou. Znalecký zákon je projednáván zde v Parlamentu od začátku roku 2018 a diskuze byly nad nim tedy intenzivni a rozsáhlé. Na základě pripomínek odborné veřejnosti a ústavněprávního výboru byl částečně tento zákon i prepracován. Nyni je předmětem kritiky ze strany některých senátorư, ale já mám za to, že ta kritika neni spravedlivá a je poněkud předimenzovaná. Nejedná se o adekvátni kritiku a bylo by neštastné, kdyby tento zákon nakonec nebyl schválen, protože tato země jej podle mě potřebuje a př́mo po něm volá.

Hlavni výhrada, která zazněla ze strany Senátu, je centralizace znalecké agendy na Ministerstvo spravedlnosti. Já musím ale zdi̊raznit, že centralizaci, tento návrh, doporučil právě ústavněprávní výbor Poslanecké sněmovny a dohled ministerstva považuji za účelnějši než stávající dohled krajských soudů. A jako argument mám zkušenost, že soudy především by mély soudit, a ne se tedy věnovat takovéto správni činnosti, která jim nepřisluši. Ministerstvo spravedlnosti navic je velmi dobře vybaveno na tuto kontrolní činnost a má své zkušenosti, pokud je o tyto profese. $V$ současné době existuje odbor, který se znaleckou činností intenzivně zabývá, a máme i poradni sbory, kde se tedy odborné otázky konzultuji, a kde tedy máme možnost tyto připomínky vyslyšet a nějak propracovat. V těchto sborech máme odborniky $v$ daných profesich.

Stávajici podoba zákona je výsledkem dlouhodobého projednáni a také celé rady kompromisư. Zájmy v oblasti znalectví jsou extrémně rozdílné a jediné, co je spojuje, je v podstatě požadavek na vyšši finančni ohodnocení. Dnešní zákon nepovažuji za funkční, dohled nad znalci neni efektivní. To jistě máte tu čest sledovat i z různých televiznich reportáží. Systém potřebuje změnu a věřim, že nový zákon by prispèl ke zkvalitnění a stabilizaci znaleckého odvětví.

S ohledem na tyto skutečnosti, které jsem zdưraznila a které už jste tady několikrát vyslechli, a já je jenom opakuji, bych vás chtěla touto cestou požádat, abyste hlasovali pro prijetí tohoto zákona a přehlasovali ten poněkud zbrklý názor Senátu, který byl zaujat. Děkuji za pozornost.
Jako další vystoupil senátor MUDr. Lumír Kantor, Ph.D., (pozn.: znalec z oboru zdravotnictví - pediatrie - neonatologie (novorozenecké lékařství) ${ }^{3)}$ ), aby se vyslovil ke stanovisku Senátu, proč zamítl návrh zákona:

Vážený pane predsedajicí, vážené pani poslankyně a váženi páni poslanci, já si za Senát PČR dovolím udělat jakýsi úvod ke v̌̌em třem tiskům, které půjdou po sobě, a potom se vyjádřím kjednotlivým tisküm.

Vyšse uvedené návrhy zákonů byly na plénu Senátu projednány dne 2. května 2019. Tehdy predtím to měly dva senátni výbory. Ústavněprávní výbor jako garanční výbor doporučil zamitnutí všech tři návrhů a výbor pro zdravotnictvi a sociální politiku doporučil vrátit návrh zákona s pozměňovacimi návrhy a neprojednával sněmovni tisk číslo 73, návrh zákona o soudnich tlumočnících. A ten třetí zákon potom jsme doporučili schválit ve znění postoupeném Poslaneckou sněmovnou. Plénum Senátu schválilo návrh na spojeni obecné rozpravy ke všem shora uvedeným návrhi̊m zákona. V obecné rozpravě vystoupilo osm senátorů, z toho jedna senátorka dvakrát. Na základě následné diskuse na plénu Senátu byly nakonec všechny tři návrhy zákonů zamitnuty. Odůvodněním na půdě Poslanecké sněmovny jsem byl pověren já, Lumír Kantor, s panem senátorem Zdeňkem Hrabou. Pozměňovaci návrhy výboru pro zdravotnictvi a sociální politiku nebyly nakonec hlasovány vzhledem k tomu, že Senát rozhodl predložené návrhy zákona zamitnout.

$Z$ výše uvedených diovodi tedy za Senát Parlamentu ČR žádám zdvořile Poslaneckou sněmovnu o podporu senátnich návrhů, tedy o zamítnutí tisku 62, poslanecký 72, 63, poslanecký 73, a 67, poslanecký 74 .

Ted' ohlednè zákona o znalcích a znaleckých kancelárích a znaleckých ústavech. Hlasování číslo dvacet čtyři proběhlo tak, že z prítomných 67 senátorů hlasovalo pro zamítnutí 39 senátorů, proti zamítnutí 4 senátoři a 24 senátorů se zdrželo. Dưvodem zamitnutí zákona byla především centralizace znalecké agendy na Ministerstvo spravedlnosti jako orgán politický. Dále byla kritizována obsáhlost navrhovaných zákonů, kdy oproti dosud platné právni úpravě docházi fakticky ke zdvojeni legislativniho textu. Nepřiměrené penzum povinnosti vyplývajici z nové právni úpravy pro znalce a tlumočníky. V neposlední radě drakonické sankce ukládané na základě objektivní odpovédnosti za souběžného vypušténi limitace správního trestu. Potom tam jsou nejasnosti, a kontroverze vyvolávala rovněž promlčecí doba přestupkové evidence znaleckých posudkü. A byly zminěny některé výhrady týkajici se... takové dilči problémy. Např́klad zkráceni pưvodni délky praxe soudních znalců z vládním návrhem daných deseti let na pozměňovacím návrhem daných pět let. Napřiklad to by mohlo znamenat, že lékař, který má v podstatě po škole a nemá ještě hotovou atestaci, už může psát soudněznalecké posudky. Mohlo by se stát takto.

V diskusi zaznívaly rovněž hlasy podporujici prijietí navrhovaných zákonů zejména sohledem na nutnost přijetí nové právní úpravy $s$ akcentem na stáři dosavadnich zákonů.

Z výše uvedeného důvodu tedy za Senát Parlamentu ČR žádám zdvořile o podporu senátního návrhu, tedy o zamítnutí senátního tisku 62 a poslaneckého tisku 72. Dékuji.

\footnotetext{
3) http://datalot.justice.cz/justice/repznatl.nsf/0/F8745A31EB816C57C 12584660057F430?OpenDocument
} 
Zpravodajkou PS byla poslankyně paní prof. JUDr. Helena Válková, CSc.:

Milé kolegyně, mili kolegové, já jsem tady rečnila hodněk tomuto zákonu. A tenkrát, jestli si vzpomináte, ve sněmovně jsem i řekla, že si beru za úkol vyjit vstřic těm námitkám, o kterých tady hovořila paní ministryně. V létě 2018 jsme připravili v úzké součinnosti s Ministerstvem spravedlnosti komplexní pozměňovací návrh, který se týká nejenom znalců, ale i tlumočníků, a toho sněmovního tisku 73, to znamená souvisejicich zmènových zákonů.

Myslim si... jako zpravodajka, byl s nimi vysloven souhlas i na ústavněprávním výboru, a proto mè velmi překvapilo potom, že někteři kolegové setrvali na svém zamitavém stanovisku, $i$ když neformálně vědi a znaji velice dobře, jak nám současný znalecký stav, resp. situace v oblasti znalecké činnosti komplikuje život. Jak některé soudni procesy se protahuji a jak potom na to dopláci $i$ běžný občan. Protože pochopitelně když je někdo bud' zproštěn nebo když se dlouho soudi, potom žádá o odškodněni stát, tak nakonec to zaplatíme my všichni.

Nezřidka, nikoliv výjimečně, jsou u zrodu těchto problémů právě znalecké posudky, které jdou proti sobě, a samozřejmě se musi nařizovat i revizni znalecké posudky. Je to kromě jiného dané i tím, že zde neexistuji standardy, které by nařizovaly znalcưm, aby dodržovali určitý postup, aby tak, jak třeba k pozméňovacímu návrhu pana poslance Michálka i zdi̊vodňovali pravděpodobnost objektivity a relevantnosti svých závěrư, př́padnè vysvètlovali, proč se nelze na ně spolehnout, na závěry toho znaleckého posudku, stoprocentnè.

Dalši návrhy, které jsme zapracovali, zaznèly od pana poslanec Ondráčka z KSČM. Čili opravdu to šlo, tento zákon, napřič politickým spektrem. A bylo by ted' neštastné, kdyby tato soudni reforma, protože já tomu ríkám - tady nejde jenom o reformu znalecké činnosti, ale bude to přmo ovlivňovat i rozhodováni soudù, čili v preneseném smyslu slova soudni reforma byla vetem Senátu, které není dobře zdi̊vodněné. Navíc použivá argumentaci, která je částečně i neobjektivní, protože kritizuje néco, co v tom návrhu bylo přiloženo. Viz např. kritické připomínky $k$ absenci vyhlášek, odvoláváni se na body, které tam nejsou, nebo jsou vjiném pořadi. Takže kdyby byl tento návrh po tolika měsicich, vlastně dvou a pưl letech úsilí, neschválen, a tím celá práce by šla vniveč.

Čili připojuji se $k$ doporučení, aby zákon o znalcích a s tím úzce související zákon o tlumočnících - já už k tomu zákonu o tlumočnicich asi vystupovat nebudu jako zpravodajka, protože to je bezprostředně spojené a spjaté - a souvisejici zákony byly Poslaneckou sněmovnou schváleny, a to $v$ tom potřebném počtu hlasů 101. Dékuji.

Následovala rozprava; vzhledem k důležitosti zákona pro znaleckou obec dovolujeme si citovat ze stenoprotokolů takřka plné znění.

Poslanec Marek Benda: Vážený pane mistopředsedo, vážená pani ministryně, vážení páni ministři, ministrynè, dámy a pánové, já snad jenom stručně chci zdůvodnit, proč my nepodpořime pưvodní usneseni Poslanecké sněmovny a budeme hlasovat v tomto př́padě se Senátem.

Já bych skoro řekl, že to dokonce není vina ani nikoho z těch, kteři jsou dnes tady v sále prritomni. Nová paní ministryně za to nemůže. Nepochybně paní kolegyně Válková ve snaze opravit návrh zákona pripravený panem ministrem Pelikánem odvedla velké množství práce. A já ho nijak nezpochybňuji. Přesto si myslím, že prostě norma tohoto charakteru, která, jak bylo tady řečeno, přináši reformu v jedné části justični práce, což je právě znalecká činnost - $k$ té tlumočnické se dostaneme v prrištím bodu, kde budu možná ještě o kousek kritičtějši -, se má zpracovávat opravdu na ministerstvu, s ř́ádným připomínkovým ř́zením, a ne tak, že bývalý pan ministr si něco připravil už v roce 2016, pak mu to neprošlo Poslaneckou sněmovnou, téměr bez jakékoliv opravy, bez jakékoliv snahy se domluvit s jednotlivými profesními uskupeními, vyslechnout si všechny strany, které tady vystupují, protože těch znalcủ je opravdu velikánská rada, v radě oborů, s úplně jinou velikostí, at' už znaleckých kanceláří, znaleckých ústavů, nebo i váhou a velikostí znalců. Někdo se tím je schopen živit úplně, někdo dělá jenom občas nějakou činnost. Prostě je to velmi různorodé a mělo se tam mnohem pečlivěji vážit.

Já si vážím toho, co odvedla na věci paní kolegyně Válková. Myslím, že se pokusila ten návrh zákona vylepšit. Ale přesto se domnivám, že by bylo lépe, aby se ministerstvo a vláda jako celek znovu nad tím zamyslely. Já prostě nesouhlasím vnitřně s tou úplnou centralizací, ke které má dojít tím, že všechno se má rozhodovat na Ministerstvu spravedlnosti ve Vyšehradské. Tuto centralizaci pokládám za nešt'astnou. Těch různých typů znalců, znaleckých ústavů, znaleckých kanceláři je přiliš velké množství. A pak samozřejmě snaha rozhodovat to všechno z jednoho mista, nevytvořit tam alespoň minimální konkurenci - a dobře, možná se dneska vedou polemiky o tom, jestli ten který predseda soudu nejmenuje přiliš benevolentně, ten který predseda soudu naopak není přiliš př́sný ve jmenování znalce nebo znalecké kancelářre. Ale ten fakt, že to pak všechno zcentralizujeme na jedno misto a budeme mit pocit, že to bude mnohem objektivnější, já z toho mám velké obavy, já tomu prostě nevěrim. Já celý život věrim na jistou míru konkurence, nevěrím na to, že centralizace na jednom mistě je to, co nám pomůže.

Z tohoto důvodu náš poslanecký klub nepodpoři původni usneseni Poslanecké sněmovny, bude podporovat rozhodnuti Senátu. Domniváme se, že by bylo nejlépe, aby se vláda is tím, co už bylo odpracováno, znovu $k$ návrhu vrátila a znovu po rádném připomínkovém řizeni a zejména po vypořádáni všech těch zájmových a profesnich skupin prì̌sla s opraveným návrhem zákona. Proto budeme hlasovat proti.

Poslanec Mgr. et Mgr. Jakub Michálek: Vážený pane mistopredsedo, vážená vládo, vážené kolegyně a kolegové, já už jsem tady taky vystupoval v minulých rozpravách. My se snažíme konstruktivně zachovávat podle obsahu návrhu. Pokud jde o tu základní myšlenku návrhu zákona o znalcích, to znamená, aby došlo $k$ centralizaci dohledové činnosti nad znalci, tak to je věc, kterou já absolutně podporuji. Protože ten současný systém, kdy je to decentralizováno na těch soudech, má několik vážných nedostatkư, včetně toho, že my jako poslanci nemůžeme řešit ta podání, která dostaneme, a kdy si lidé, novináři, veřejnost, stěžují na to, jakým zpưsobem v některých oblastech kontrola znalecké činnosti probíhá, nebo spiš neprobihá.

My tady samozřejmě nemůžeme interpelovat logicky předsedy soudu, to by asi opravdu úplně nefungovalo. Ale pokud se ta činnost prevede na Ministerstvo spravedlnosti, tak ty věci, podněty, připomínky budeme moct předávat Ministerstvu spravedlnosti, tak 
aby náležitě vykonávalo dohled nad znalci. Všichni velmi dobře známe, že se znaleckou činností je spojena celá rada úskalí, výhrad, stojí na tom opravdu velké kauzy. Je tam velký problém s tím, že oceněni znalců neodpovidá tržni úrovni, klesá zájem o to, aby lidé vykonávali znaleckou činnost, a tak dále.

Takže já jsem v tomto prípadě spíše na straně toho, aby ten návrh v té podobě, jak jsme ho v Poslanecké sněmovně schválili, vešel v platnost. Protože pokud se nám nepodaři ted' provést tu centralizaci znalecké činnosti, tak už se v tomto, respektive $v$ dohledu, tak už se to zkrátka do konce volebniho období nepodaři, což by byla škoda.

Nám se tam podařilo prosadit i některé věci, které považuji za důležité. Napřiklad standard pro určitou úroveň spolehlivosti toho znaleckého posudku, tak aby se to bližilo nějaké vědecké úrovni, aby tam byla jednodušši prezkoumatelnost, tak aby skutečně ti soudci se na to mohli spolehnout a méli jasné voditko, podle kterého ty znalecké posudky př́padně přezkoumávat.

Současně považuji za nezbytné promluvit o zákonu, který je s tímto spojen, protože tady v podstatě projednáváme jeden balik, což jsou sněmovni tisky 72 až 74 - znalci, tlumočníci a změnový zákon. Všichni dobře víme, že ty zákony, sněmovni tisky, jsou tak propojené, že si nemůžeme dovolit situaci, že bychom jeden z nich schválili a některý neschválili. ...

My jsme samozřejmě jednali - a já v tomto ohledu absolutně respektuji výhrady odpůrců, které zaznély $k$ tomu návrhu o tlumočnícich, jakjsem řikal. Ani my jsme nebyli uspokojeni tak, aby se ty absurdni věci, které tam dneska jsou, že si ten tlumočnik bude muset doma v kamrliku schraňovat ty překlady, které učinil, ačkoliv už jsou na tom soudu nebo na tom orgánu veřejné moci, který je poř́dil, tak aby se ty absurdity a výhrady vyřšily, zlikvidovaly. My jsme o tom jednali s pani kolegyní Válkovou $z$ ANO. A pokud dostaneme př́slib, že bude novela, která nabude účinnosti spolu s tou legislativou, to znamená, pokud se nám opravdu podaři vyřešit, opravit ty chyby, které jsou v tom zákoně o tlumočnicich, tak my, pokud tady dostaneme ten př́slib, ten návrh zákona taky podpořime, tak aby nedošlo k chaosu a byli schváleni jak znalci, tak tlumočnici. Ale je opravdu potřeba, aby tady zazněl jasný závazek ze strany, řkněme, té politické části zodpovědné vládní koalice, že tyto věci se opraví, protože jak jsem řekl, máme s tím vážné problémy. A pokud nebudeme mit jistotu, nebo alespon̆ nějaký rozumný stupeň jistoty, že k té opravě, shodě dojde, tak ten návrh podpořit nemüžeme.

Děkuji za pozornost.

Poslankyně prof. Helena Válková: Ano. Takjá reaguji na projev svého přdrečníka pana poslance Michálka. Nevím, jestli tedy mohu vůbec dávat nějaké závazné př́sliby. Ale to, co müžu slíbit, že určitě - protože vím, o jakou novelu jde, vedli jsme o tom diskuzi. Jde o archivaci po určitou dobu, z původnich deseti let se to zkrátilo na tři roky. Ani ty nejsou dostatečné, já chápu kolegy. Mluvila jsem také samozrejmě v mezidobí s tlumočníky, s některými tedy. Takže oni to, myslim, nevidi tak dramaticky. Ale vidi to dramaticky dost na to, že nechtěji archivovat. Takže ne že by ten zákon jako takový nechtèli, ale nechtějí archivovat. Alespoň pokud jsem to pochopila $z$ vyjádřeni některých.

Takže já tomu vycházím vstřic, protože si myslim, že kompromisy člověk má dělat, v politice dvojnásob, pokud to neméní obsah, páteř, systém a smysl reformy. A to rozhodně nemění. To rozhodně nemění,
... ten návrh té novely, pokud ji pan poslanec Michálek a jeho kolegové pripraví, spolupodepísi ráda, nebudu mit pocit, že dělám něco za něco, že je to nějaký byznys. Budu mit pocit, že vycházím vstřic jedné profesní skupinè. A v rámci svých možností, dobrých vztahů s Ministerstvem spravedlnosti si myslím, že k tomu konsenzu v rámci té relativně dlouhé legisvakančni lhưty dojdeme. A bude záležet už samozřjejě na poslancích. A tady asi už nemůžu slíbit nic, ale za nás můžu předslíbit, že k takové zméně budeme vstřicní.

Takže za mě to, co můžu slibit, a to, co nemůžu slíbit, tak tam je třeba určitá di̊věra v politickou kulturu. A i právní. A tou novelou by určitě ta právni kultura ohrožena nebyla. Děkuji.

Poslankyně PhDr. Olga Richterová, Ph.D.: Vážená paní ministryně, váženi dalši přitomní členové vlády, vážené kolegyně, váženi kolegové, já bych se ráda vyjádřila $k$ tomuto baliku bodů, protože opravdu ty dva zákony jsou siamská dvojčata, nelze je oddělit. Netušila jsem, když jsem byla zvolena do Sněmovny, že využiji i svoji pưvodní profesi - a sice já jsem vystudovaná tlumočnice, prekladatelka. Čili logicky mám v tomto oboru řadu kolegů.

Neni mi lhostejné, že naše pozměňovaci návrhy, které jsme předkládali, byly prostě smeteny ze stolu. Jsem ráda, že Senát znovu upozornil, že opravdu ty chyby jsou závažné. Současně respektujeme to, že je potřeba novela zákona o znalcích. Jsem ráda, že pani poslankyně Válková príslibila vlastně svoji podporu, abychom připravili nápravu ve věcech týkajících se soudních tlumočníkü. Je to pro nás jediná možnost, aby skutečně nedošlo i k významnému ohroženi veřejného zájmu. Já k tomu ještě něco řeknu podrobněji.

Možná si totiž, vážené kolegyně, váženi kolegové, mnozi z vás neumite představit, co obnáši profese soudniho tlumočníka a proč je to tak celé i kličové pro zaručeni skutečného práva na soudni ochranu. Jde o to, že je potřeba tlumočit nejenom z běžných jazykư, z jazykư, které skutečně umi kde kdo, ale i zjazyků velmi vzácných. A ten zákon má dopadnout na všechny.

Stejně tak si prosím predstavte, že komerčni tlumočníci, kterých je samožrejmě většina, kteři pracuji na volném trhu, komerční tlumočnici mají úplně jiné sazby, než za jaké dnes tlumoči ti tlumočníci soudní. Jen malá část tlumočníků dělá oboje. Takže si musime klást otázku proč, proč si ti komerčni neprivydělávaji i tím, že by byli tlumočníky soudními? A zase, už to tady zaznělo, že právě třeba to ohodnocení není dneska dostatečné. Ale ony jsou naprosto nesrovnatelné i ty podmínky. Je zkrátka něco úplnějiného, pokud vystudujete tlumočení, jste jaksi naučeni fungovat s určitým typem klientů, a potom se máte setkávat s pachateli trestných činů, být kdykoliv $k$ dispozici. Zkrátka ta psychologická zátěž je také nezanedbatelná. A toto je standardní agenda soudních tlumočníků.

Ráda bych ještě jednou shrnula, že už dnes maji tlumočníci vlastně jak správní, tak trestní odpovédnost. A ten návrh zkrátka ty sankce ještě zpřisňuje, a přitom vlastně neošetřuje práva. Neošetřuje, aby ty uložené povinnosti byly přiměrené poměrưm ve výkonu profese. Jednak už to je ta zmiňovaná archivace, ale jde i o dalši věci. Ještě jednou zdůrazňuji, pokud dojde $k$ nedostatku tlumočníků pro určitý jazyk, tak vlastně potom budou orgány veřejné moci odkázány na to, že budou jednorázová ustanovování. A tam absolutně není možné zaručit, že ten jednorázově ustanovený člověk bude mit všechny odborné předpoklady, aby splňoval také požadavek nezávislosti a nestrannosti.

Poslední bod. Chci zdirraznit, že vi̊bec celkový dopad toho současného návrhu zákona může být, že to prostě dál odradí 
zejména nedostatkové tlumočníky vzácných jazykư, tlumočniky $v$ regionech a také, a to zase ještě nebylo zmíněno, tlumočníky pro komunikaci s osobami neslyšicími, nevidomými a hluchoslepými. I těchto tlumočniků je už dnes nedostatek.

Jediná možnost pro Piráty, abychom hlasovali pro balik těch dvou zákonů, je opravdu př̀slib, že i když to bude námi připravený návrh zákona spolu s poslankyni pani profesorkou Válkovou, tak že bude urychleně projednán, aby opravdu během té legisvakančni lhůty $v$ těchto věcech mohlo dojít $k$ zjednáni nápravy. Děkuji.

Ministryně spravedlnosti ČR Mgr. Marie Benešová: Já bych chtěla ještě jednou zdưraznit, že ty tři zákony jsou natolik provázané, že jeden bez druhého nemũže být, takže zvažujte pečlivě, jak to tedy je.

A chtěla bych poděkovat Pirátům za prekvapivý konstruktivni názor, který tedy oceñuji, a myslim si, že vždycky musíme myslet na to, co je podstatné a co je nepodstatné. A tady pani profesorka to řekla jasně. My tam leccos oželíme, můžeme to i novelizovat $v$ budoucnu. Já netvrdím, že je to světoborný, úplně maximálně správný zákon, některé ty věci můžeme vychytat a nějakou malou novelu tam pak udélat. Dékuji.

Senátor MUDr. Lumír Kantor, Ph.D.: Ještě k tomu senátnímu tisku 63, vašemu tisku 73. O návrhu zákona o soudnich tlumočnícich a soudnich překladatelich hlasovalo v hlasování z přitomných 68 senátorü pro zamítnuti 52 senátorü, proti zamitnuti 4 senátoři a 12 senátorů se zdrželo. Obracela se v hojné míre odborná veřejnost, organizace sdružujici tlumočniky a překladatele, $k d y$ zcela převažujicí názor k navrhovaným zákonům byl ostře odmitavý.

Nejpodstatnějši výtkou odborné veřejnosti bylo neúměrné stanovování dalšich povinností a významné navyšování sankci za stavu, kdy odměny znalců a tlumočníků jsou dlouhodobě nedostatečné.

Jako základní nedostatek zákona o tlumočnícich se jeví zjednodušená paralela zákona o znalcích a tlumočnícich. Tady je potreba si uvédomit, že znalec není tlumočnik, a naopak. Každá taková profese má svá specifika. Téměř identický zákon je pro současných 3000 tlumočniku naprosto nevhodný předevšim $z$ di̊vodu navrhované zákonné regulace profese soudniho tlumočníka i prekladatele, nereflektuje specifika právně tlumočnické a právně překladatelské činnosti. Ta vyžaduje víc než pouhou jazykovou kompetenci. Tato profese zásadním způsobem ovlivňuje výkon veřejné správy a spravedlnosti.

Zákon stanovi podmínky vzniku tlumočnicko-prekladatelského oprávnění, ale neupravuje dalši odborný růst tlumočníků a prekeladatelư. Dalši odborné vzdělávání je zcela nezbytné a mělo by být uloženo i prrinejmenším v obecné rovině v zákonu. Možnost odmítnout tlumočnický překladatelský úkon je nepřiměřeně omezena. Ze strany státu neexistuje garance stálého př́sunu zakázek a většina tlumočniků tak vykonává své zaměstnání, jiné zaměstnání nebo samostatnou činnost, takže to neumožňuje např̀iklad, ta novela, odmitnout zaměstnanému tlumočníkovi úkon, který má být proveden v jeho pracovní době, a nemůže odmitnout úkon, na který se neciti odborně kompetentní.

Maximálni sazby pokut jsou př́liš vysoké, jednak vzhledem k povaze přestupků a vzhledem k tomu, že tlumočníci a překladatelé jsou fyzické osoby, z nichž malá část má výrazně nadprůměrné príjmy. Napřklad v oblasti takzvaným malých jazyků je výkon omezen na několik tlumočení či překladů ročně.
V Senátu byla dne 12. 8. 2019 konstituována pracovní skupina ze sedmi profesnich organizaci s presahem do evropského prostoru $i$ malých či znakových jazyků. Dalšimi členy jsou vzdělávaci instituce a skupina senátorů. V připadě zamítnutí zákona o tlumočnících by došlo k doladèní zákona i dle potřeb tlumočníku $v$ souladu s potřebami a požadavky Ministerstva spravedlnosti. To je možné i při schválení tisku 62 a 64 senátního, neschválení tisku 63. V prípadě schváleni ostatních tiski̊ tedy bude nutné tento nově navrhovaný zákon schválit doslova do roka a do dne. To je reálné, nebot' účinnost je navrhována k 1. 1. 2021.

Z výše uvedených dưvodů tedy za Senát Parlamentu České republiky žádám zdvořile Poslaneckou snémovnu o podporu senátniho návrhu, tím tedy o zamítnuti tisku senátního 63, poslaneckého 73.

Děkuji za pozornost.

Místopředseda PSP JUDr. Vojtěch Filip: Zazněla závěrečná slova. Já jsem zagongoval, ještě zagonguji jednou. A ještě mi došla oprava omluvy pro predsedu Poslanecké sněmovny od pana poslance Václava Klause, a to dnes od 18.30 hodin do konce jednacího dne z osobnich di̊vodi̊ a zitra 11. 9. od 9 do 13 hodin a potom od 15 hodin do konce jednaciho dne z pracovnich dìvodi.

Přistoupíme k hlasování. Podle § 97 odst. 3 zákona o jednacím rádu Poslanecké sněmovny k přijetí následujicího usnesení je zapotřebi souhlasu nadpolovični většiny všech poslanců, kteři souhlasí, 101 poslance. Máme - ještě nemáme nastavené - tak máme nastavené nezbytné kvorum.

Rozhodneme v hlasování číslo 29, které jsem právě zahájil, a ptám se, kdo je pro přijetí následujicího usnesení, že Poslanecká sněmovna schvaluje návrh zákona o znalcích, znaleckých kancelárích, znaleckých ústavech podle snèmovního tisku 72/7. Kdo je proti?

(Výkřiky, neklid, poslanci nevědí, o čem se hlasuje.) Ne, to je zamitnutý zákon Senátem. Hlasuje se jenom o tom. (Nesouhlasné projevy z pléna.) Tak ještě jednou. (Nesouhlasné projevy.) Dobře, dobře. Prohlašuji hlasováni číslo 29 za zmatečné. (K řečnickému pultíku se blíží poslanec Benda.) Já rozumím panu kolegovi Bendovi.

Poslanec Marek Benda: Já prosím souhlasím s tím, že hlasováni je zmatečné, a poprosím pana mistopředsedu, aby neurychloval jednání umělým způsobem. Nejprve řekněte, o čem se bude hlasovat. Potom spouštějte hlasovaci zařizení. Ta situace, do které jsme se ted' dostali, že teprve v průběhu hlasování nám ř̉káte, o čem hlasujeme, byla pro většinu sálu opravdu matoucí. Takže bych poprosil, abychom uměle se nepokoušeli dostat př́liš...

Místopředseda PSP Vojtěch Filip: Já jsem také to hlasováni prohlásil za zmatečné.

Budeme tedy hlasovat v hlasováni čislo 30 o tomto návrhu usneseni: „Poslanecká snèmovna schvaluje návrh zákona o znalcích, znaleckých kancelárích a znaleckých ústavech podle sněmovního tisku 72/7. “

Zahájil jsem hlasováni pořadové číslo 30 a ptám se, kdo je pro. Kdo je proti? Děkuji vám.

Hlasování pořadové číslo 30: z prítomných 182 pro 107, proti 32. Návrh byl prijat. Konstatuji, že návrh zákona byl přijat. 
Děkuji paní ministryni, děkuji zástupci Senátu a zpravodajưm a končím bod čislo 1.

\section{K projednávání zákona o soudních tlumočnících a soudních překladatelích}

Po obšírné rozpravě bylo odhlasováno přerušit projednávání tohoto zákona na 60 dní. Tím ovšem nastal problém s třetím zákonem, kterým se mění některé zákony $\mathrm{v}$ souvislosti s přijetím zákona o znalcích, znaleckých kancelárích a znaleckých ústavech a zákona o soudních tlumočnících a soudních překladatelích:

Místopředseda PSP prof. PhDr. Petr Fiala, Ph.D., LL.M.: Vážené paní poslankyně, vážení páni poslanci, ... budeme pokračovat v pořadu schưze. Dostali jsme se do legislativněne úplnějednoduché situace s tím, že jsme schválili jeden zákon, ale dalši souvisejíci jsme přerušili, a nyní se s tou situací musíme vypořádat. Řě̌ení, které navrhuje legislativa, je takové, že otevřu projednávání bodu soudni tlumočníci, tedy toho třetího bodu, který máme nyni na programu, navrhnu přerušení a odhlasujeme prerušení na 60 dnü, tak jak jsme to udělali u toho předcházejícího bodu. Samozřejmé záleži na vůli Poslanecké sněmovny, jestli toto doporučeni legislativy, která ho považuje za jediné možné, hlasováním schválí.

Poslankyně Mgr. Jana Černochová: Ještě je férové kolegyním a kolegưm řict, že ta situace neni standardni i z toho di̊vodu, že ty tři návrhy spolu souvisejí. My jsme schválili jeden. Dva neschválíme, přerušime, a tady je ale problém, že samozřejmě pan předseda Sněmovny v zákonné lhuitě musí ten schválený návrh zákona, který nelze revokovat, poslat panu prezidentovi, aby ten zákon mohl nabýt účinnosti, platnosti, čímž pádem se dostáváme do složité situace, protože pan prezident dostane pouze jeden návrh, nedostane ty dalši dva navazujicí, a pak bychom vlastně měli tedy doufat v to, že bud'to nám to pan prezident - nemůže to zadržet, předseda Sněmovny to nemũže zadržet - a prezident (poznámky z pléna) - první jsme odhlasovali. Dobře, ale jde o ten první. Ten první jsme odhlasovali a pan predseda Sněmovny v zákonné lhůtě musí tento návrh poslat prezidentovi. Prezident ve lhůtě 15 dnů má dvě možnosti. Bud'to se pod ten zákon podepsat, aby byl platný a účinný, anebo nám ho vrátit, abychom my ho zase museli přehlasovat stojedničkou, črmž pádem se my dostaneme do situace, že prezident z trojice zákonů dostane jenom jeden a u těch dvou nevíme, jak tady vlastně ten proces dopadne, a nelze - tohle také jsme diskutovali s legislativounelze ten první schválený zákon tady zadržet. To by se zase dopustil porušení Ústavy pan předseda Sněmovny. Tak jenom tohle považuji za férové, abyste slyšeli všechno, co jsme projednali s legislativou.

Místopředseda PSP prof. Petr Fiala: Jenom poznámka ke stanovisku legislativy. Ústavou tady není uložena žádná lhůta pro odeslání. Z tohoto hlediska se legislativa Poslanecké sněmovny přikláni $k$ názoru, že lze počkat na schválení těch dvou dalších zákonů. Ale je to skutečně něco, co je tady nové a čím se vytváři určitá precedentni situace.

Ministryně spravedlnosti ČR Mgr. Marie Benešová: Vážený pane předsedo, vážení poslanci, poslankyně, já jsem věc konzultovala se svým předchůdcem, který dneska v podstatě působí v Legislativni radě vlády, a ten mi tady posílá esemesku, že je potřeba schválit i ten doprovodný zákon, protože jinak by z toho opravdu byl zmatek. Takže bych prosila aspoň ten doprovodný, protože tady bude nějaká jistota. Máme tedy odlišný právní názor. Já panu doktoru Kněžínkovi věřim, protože je zkušený legislativec.

Poslanec Jakub Michálek: Děkuji za slovo. Já jsem chtěl jenom podpořit to, co tady řikala kolegyně pani mistopředsedkyně Černochová. Rovněž se klonim k závěru, že bychom neméli ohýbat to, co je v Ústavě zakotveno, a to, že se návrhy zákonů po schváleni Poslaneckou snémovnou - bez ohledu na to, co si o nich myslíme, jestli jsou dobré, špatné, obsahuji chyby atd. - postupují prezidentovi republiky a ten už se může zachovat tak, jak uzná za vhodné.

Já jsem jenom chtěl uvést k tomu hlasováni, které bylo poněkud nestandardní, to určitě souhlasím, o přerušení projednání vratkycitace z komentáre kjednacímu rádu, který tedy zpracoval kolektiv autorü, že pokud se týká návrhu procesního charakteru, dosavadni sněmovni praxe připoušti návrh na odročení, resp. přerušeni bodu při projednávání návrhů zákonů vrácených Senátem, resp. analogicky při projednávání návrhů zákonů zamitnutých Senátem, viz stenoprotokol schi̊ze Poslanecké snèmovny 4. volebni obdobi, 16. schůze, 10. 6. 2003, bod čislo 116. Takže byt' jde o situaci, která je nestandardní, nejde o situaci, která by se již neopakovala. Takže myslím si, že jsme se zachovali v souladu s jednacím rádem a ústavním pořádkem. (Potlesk poslanců Pirátů.)

Poslankyně Jana Černochová: Já bych doplnila pana předsedu Michálka. Ano, už jsme v podobné situaci byli, ale ta podobná situace se týkala přerušení návrhu, který nám vracel Senát. Netýkala se situace, kdy bychom tady méli nějaký balik zákonů, který spolu souvisí. To jenom abychom zase si tady řikali ty věci úplně stoprocentně, jak jsou.

Místopředseda PSP Petr Fiala: Děkuji. Takže v tuto chvili v každém prripadě otevírám projednávání bodu 3 -Návrh zákona, kterým se méní nékteré zákony $v$ souvislosti s prijetím zákona o znalcích, znaleckých kancelárích a znaleckých ústavech a zákona o soudnich tlumočnicich a soudnich prekladatelich/sněmovni tisk 74/8/ - zamitnutý Senátem.

Usnesení, jímž Senát zamitl tento návrh zákona, bylo doručeno jako sněmovni tisk 74/9. Vitám tady znovu pana senátora. Obdržel jsem doporučení legislativy Poslanecké sněmovny, abych navrhl Poslanecké sněmovně prerušeni tohoto bodu. Já tomuto návrhu vyhovím, byt' jsem pochopil, že ne všechny poslanecké kluby si myslí, že je potřeba tento sněmovni tisk nyní přerušit, nicméně vznáším tento procedurální návrh, abychom přerušili projednávání tohoto návrhu na 60 dnů, tak jak jsme to udělali s tím predcházejícím bodem. Přivolám poslance a dám o tomto návrhu legislativy Poslanecké sněmovny hlasovat.

Zahajuji hlasování. Kdo je pro prerušeni na 60 dnů? Kdo je proti? Vhlasování ćíslo 32 prihlášeno 176 poslanců, pro 65, proti 75. Návrh nebyl prijat.

Takže prosím, aby se k usneseni Senátu o zamitnuté tohoto návrhu zákona vyjádřila za navrhovatele ministryně spravedlnosti Marie Benešová, a budeme pokračovat v projednávání. Paní ministryně, máte slovo.

Ministryně spravedlnosti ČR Marie Benešová: Vážený pane předsedo, vážené poslankyně, vážení poslanci, ten třetí doprovodný 
zákon už je v podstatě doprovodným zákonem, který navazuje na ten první, co jste schválili, v daném prípadè, protože ten druhy byl přerušen, a jak jsem se dozvěděla, naše legislativa už má $v$ podstatě připravenu tu novelu. Takže myslím si, že to zvládneme, ale potrebovala bych tento doprovodnýzákon, který bez toho prvého vlastně nemůže existovat, podpořit, protože aspoň tedy tady bude právni jistota, pokud jde o znalce, a proto prosím, abyste hlasovali pro jeho prohlasování.

Místopředseda PSP Petr Fiala: Děkuji pani ministryni. Nyní prosím pana senátora Kantora, aby se ujal slova. Prosím, pane senátore.

Senátor Lumír Kantor: Vážený pane předsedajicí, pani ministryně, vážené kolegyně, poslankyně a páni poslanci, já jenom k senátnímu tisku číslo 64, Poslanecké sněmovny 74. O návrhu zákona, kterým se měni některé zákony v souvislosti s přijetím zákona o znalcích atd., hlasovalo v hlasování čislo dvacet devět v Senátu z prítomných 69 senátorů tak, že pro zamítnutí bylo 58 senátorů, proti byli 2 senátoři a 9 senátorů se zdrželo.

Odmitnuti senátního tisku je logicky zdůvodnitelné v připadè odmitnutí ostatnich tisků z trojice zákonů o znalcich a tlumočnícich, Senátem zamitnutých. $Z$ výše uvedených dưvodů tedy za Senát žádám zdvořile o podporu senátního návrhu, o zamítnutí tisku čislo 74. Děkuji.

Místopředseda PSP Petr Fiala: Děkuji, pane senátore. A než otevřu rozpravu, tak se ptám zpravodajky garančního výboru paní poslankyně Válkové, zda si přeje vystoupit. Přeje. Prosím, máte slovo.

Poslankyně Helena Válková: Děkuji, pane místopředsedo. Milé kolegyně, mili kolegové, ten změnový zákon podle mého názoru, stejně jak už řekla paní ministryně spravedlnosti, je opravdu natolik důležitý proto, abychom uzavřeli alespoň jeden legislativni proces ohledně jednoho zákona, že nezbývá, než ho přijmout. Ti, kteři opravdu hlasovali v té stojedničce, bylo nás 107, pro zákon o znalcích, by měli zvednout ruku i pro tento zákon, protože jinak ten zákon o znalcích fakticky není komplexně schválený, protože nenavazuje a neméní ta ustanovení, která jsou nutná změnit, aby byl životaschopný. Aby prostě byl platný a účinný. Jinak jsme schválili zmetek. To je třeba tady si jasně řict. Jinak jsme schválili totálni zmetek. Řiká se tomu mrtvě narozené ditě. Nebo možná spís potracené ditě, které se ještě ani nenarodilo.

Takže bez toho zménového zákona, který méní ustanovení, která umožní, abychom mohli aplikovat zákon o znalcich - ten novýzákon o znalcich jsme v podstatě schválili jenom na formální úrovni, ale $z$ hlediska jeho platnosti a účinnosti ho nebudeme v praxi moci použivat. On bude jako platný, ale jenom v uvozovkách jako. Nikdy nemůže nabýt účinnosti. A museli bychom, a to si troufnu řict tedy na 99\%, prijmout dalši normu, která by ho udělala životaschopným, což v té krátké době, z tohoto hlediska krátké době, tedy nejde o nějakou malou technickou novelku, není v silách Poslanecké snèmovny. Čili vás opravdu prosím, abyste v tomto př́padě třeba i překonali nějaké své nechuti a zvedli ruku, pokud jste zvedli ruku pro sněmovni tisk 72, zákon o znalcích.

U toho zákona o tlumočnícich se skutečně tady řešeni ted' nabizí: ta specifika tlumočnické činnosti promitnout do novely, která nabude účinnosti ještě v době, kdy běži legisvakančni lhưta. Já jsem velmi ráda, že v tomto směru s pani ministryni souzníme a že můžu ten slib také opakovat. Ale myslím si, že hodně bude záležet i na těch, kteři vyvolali tuto aktivitu, to znamená na poslancích za Piráty, jestli ji využijí v rozsahu, který bude užitečný pro tlumočniky, anebo této šance využijí, tak jak by mohli. Děkuji.

Poslanec Dominik Feri: Dékuji za slovo, pane mistopředsedo. Já si dovolím paní kolegyni Válkovou opravit. Neni to tak, že my jsme schválili zmetek. Vy jste schválili zmetek. Vy jste schválili zmetek tím, že jste nedopráli vỉbec během toho projednávání sluchu námitkám opozice, a ted' tady šturmujete stojedničku na úplnè tu posledni chvili.

Já se přikláním k tomu, že zdravé řě̌ení je postoupit to... ten bod prerušit, postoupit to na Hrad. A pak tedy apelujte na pana prezidenta, at' uplatni suspenzijni veto a vrátí nám to zpátky. Ale po mém soudu prostě není vhodné tento zákon pouštět dál. Protože... Ano, paní ministryně má pravdu. Tento zákon je změnový, je doprovodný. Ale on není doprovodný jenom tady k tomu, co jsme schválili. On je doprovodnýk těm tlumočníkům. Vy zkrátka prijímáte změnový zákon, který mění něco v souvislosti s něčím, co nebylo prijato. To nedává vi̊bec žádného smyslu.

A já si dovoluji predložit ještě opakovaně ten procedurální návrh k tomu, abychom to přerušili na 60 dnů. V tomto př́padě to dává smysl. (Námitky ze sálu.) Tak v tom př́padě 59 dnư.

Místopředseda PSP Petr Fiala: Ano, pokud zazněl návrh na 59 dnů, abychom přerušili, procedurální návrh, tak o tom hlasovat můžeme. Kdyby to bylo na 60, o tom hlasovat nemůžeme. ... Přivolávám poslance z predsáli a budeme hlasovat o procedurálním návrhu, kterým bychom přerušili tento bod na 59 dní. (Chvilku čeká.)

Zahajuji hlasování. Kdo je pro? Kdo je proti? Hlasování číslo 33, přihlášeno 178 poslanců, pro 69, proti 73. Návrh nebyl přijat.

Pokračujeme v rozpravě. Nyni s prednostním právem pan místopředseda Pikal. Prosím, máte slovo.

Místopředseda PSP Vojtěch Pikal: Děkuji. Neni to k věci. Jenom jsem chtěl uvést svůj názor procedurálni, abych tak řekl, že přerušeni před zahájením rozpravy a během již zahájené rozpravy považuji za procedurálně jinou věc, protože ted' už např́klad zazněla úvodní slova, což mohlo situaci změnit pro některé. Nicméně tolik asi k tomu proběhlému hlasování.

Místopředseda PSP Petr Fiala: Děkuji za názor. Ale nezpochybřujete postup, ano? Nyní s faktickou poznámkou pan predseda Výborný. (Rozruch v sále.) Ne, nemá faktickou poznámku. Ještě se někdo hlásí do rozpravy? Nehlásí, tedy rozpravu končím. Je zájem o závěrečná slova? Není zájem o závěrečná slova.

Takže pristoupíme k hlasování. Přistoupíme k hlasováni podle § 97 odst. 3 zákona o jednacím řádu Poslanecké sněmovny. To znamená, že $k$ prrijetí následujicího usneseni je zapotřebi nadpoloviční většiny všech poslanců, tedy souhlasu 101 poslance. Už máme toto kvorum nastaveno.

Přednesu návrh usnesení: „Poslanecká sněmovna schvaluje návrh zákona, kterým se mění některé zákony v souvislosti s prijietím zákona o znalcích, znaleckých kancelárích a znaleckých ústavech a zákona o soudnich tlumočnícich a soudnich prekladatelich, podle snèmovního tisku 74/8“. 
Zahajuji hlasování. Kdo je pro? Kdo je proti? Hlasování číslo 34, přihlášeno 178 poslanců, pro 117, proti 32. Konstatuji, že návrh zákona byl prijat.

\section{ZÁVĚR}

Takže:

- u přijatého zákona o znalcích, znaleckých kanceláŕích a znaleckých ústavech je dán i podpis prezidenta republiky, účinnost je od 1. ledna. 2021,

- projednání zákona o soudních tlumočnících a soudních překladatelích je o 60 dní odloženo

- a přitom byl přijat návrh zákona, kterým se mění některé zákony v souvislosti s přjietím zákona o znalcích, znaleckých kancelárích a znaleckých ústavech a zákona o soudních tlumočnících a soudních překladatelích, rovněž s účinností od 1. ledna 2021.

Zájemci mohou znění zákona o znalcích, znaleckých kancelářích a znaleckých ústavech schválené Poslaneckou sněmovnou, zamítnuté Senátem a následně Poslaneckou sněmovnou přehlasované a přijaté najít na webu Poslanecké sněmovny $w w w$. psp.cz jako sněmovní tisk č. 72/7 o rozsahu 28 stran ve formátu *.docx nebo *.pdf, související zákony jsou sněmovními tisky č. 73/5 resp. 74/8. Podrobný rozbor k novému znaleckému zákonu stejně jako k přijaté novele zákona o EET ve vztahu ke znalcům přineseme v dalším čísle SI.

\section{Po uzávěrce:}

Podle posledních informací na https://www.sbirka.cz/POSL4TYD/19-1100.htm mají být schválené předpisy uveřejněny v částce 1102019 Sbírky zákonů pod čísly:

254.

Zákon o znalcích, znaleckých kancelářích a znaleckých ústavech

255.

Zákon, kterým se mění některé zákony v souvislosti s přijetím zákona o znalcích, znaleckých kancelářích a znaleckých ústavech a zákona o soudních tlumočnících a soudních překladatelích

\section{Správná citace:}

BRADÁČ, A. Nový zákon o znalcích v Parlamentu ČR. Soudní inženýrství, 2019, 30(3), 62-69. DOI: http://dx.doi.org./10.13164/ SI.2019.3.62. ISSN 1211-443X. 